\title{
ÉTUDE « IN VIVO \# DE L'ABSORPTION DES GLUCIDES A L'AIDE D'UNE MÉTHOde EN CONTINU CHEZ LE PORC
}

\author{
C. FÉVRIER, A. RÉRAT et A. AUMAITRE \\ Station de Recherches sur l'Élevage des Porcs, \\ Centre national de Recherches zootechniques, I. N. R. A., \\ 78 - Jouy-en-Josas
}

Après avoir mis au point une méthode d'exploration de l'absorption des glucides chez le Porc (Aumaitre et al., I969) nous avons cherché à mesurer qualitativement les variations de la glycémie porte en fonction de la nature des glucides ingérés. De plus, nous avons cherché à mesurer quantitativement l'absorption des glucides par dosage simultané de la glycémie du sang porte et du sang périphérique. En effet, la glycémie périphérique post-prandiale est très élevée chez le Porc, ce qui peut poser le problème du rôle du foie dans cette espèce, mais surtout constitue un risque d'erreur important pour l'appréciation de l'absorption par la seule mesure de la glycémie porte. Deux méthodes de mesure sont utilisées, le dosage de la glycémie vraie (glucose vrai par la technique à la glucose-oxydase (HUGUETT et NixON I957), et le dosage des substances réductrices totales par le dosage au ferricyanure.

Les premiers résultats nous permettent de caractériser plusieurs types de courbes d'absorption des glucides suivant leur nature : le glucose et le saccharose sont absorbés rapidement; par contre, l'amidon qui doit subir une hydrolyse préalable est absorbé à une vitesse plus lente. On peut ainsi caractériser l'absorption intestinale par sa durée après le début d'un repas de $400 \mathrm{~g}$ de glucides; de même, on peut noter l'amplitude de la variation de la glycémie. Pour le glucose et le saccharose, l'absorption dure environ 4 heures, temps nécessaire pour retrouver la glycémie à jeun.

Après un repas à base d'amidon, le temps d'absorption est beaucoup plus long, supérieur à 6 heures en général. De même, ce temps varie suivant la nature de l'amidon : l'amidon de maïs est digéré plus rapidement que l'amidon de manioc. L'amidon de pomme de terre crue ne semble pas donner lieu à une absorption de glucides très élevée, et l'on peut poser la question de son mode de digestion chez le Porc. Il en est de même pour le lactose qui est absorbé à une vitesse très lente, et qui provoque seulement une très légère augmentation de la glycémie porte.

De plus, les traitements technologiques (gonflement, dextrinisation, solubilisation de l'amidon) entraînent une augmentation de la vitesse de digestion et d'absorption du glucose dans la veine porte. Ainsi, l'amidon gélifié est digéré plus rapidement que l'amidon de maïs cru; les dextrines sont digérées et absorbées d'autant plus rapidement que leur solubilité est élevée.

Les principaux résultats nous permettent seulement de décrire qualitativement l'absorption des glucides mais nous pensons passer rapidement au stade de la description quantitative.

\section{SUMMARY}

“ IN VIVO "STUDY OF CARBOHYDRATE ABSORPTION IN THE PIG BY MEANS OF A CONTINUOUS METHOD

After having devised a method for examining the absorption of carbohydrates in the pig (AUmaitre et al., I969), we have made qualitative measurements of the variation in glycaemia in the portal vein with relation to the type of carbohydrate ingested. In addition, quantitative 
measurements of carbohydrate absorption have been made by a simultaneous determination of glycemia in the portal and the peripheral blood. Post prandial peripheral glycaemia is very high in the pig, a fact which brings into question the role of the liver in this species, but constitutes, above all, an important source of error in the determination of absorption, if only portal glycaemia is measured. Two methods of measurement have been employed, the determination of true glycaemia (glucose determination by means of glucose oxidase, Huguert and NIXON 1957), and the determination of total reducing substances using ferricyanide.

Depending on the nature of the carbohydrate, several types of carbohydrate absorption curves may be distinguished from the first results : glucose and sucrose are absorbed rapidly, while, in comparison, starch is absorbed more slowly, after a preliminary hydrolysis. Intestinal absorption may thus be characterized by its length after the start of a meal containing $400 \mathrm{~g}$ of carbohydrate, and the range in variation of glycaemia can be noted. In the case of glucose and sucrose, absorption lasts for about 4 hours, the time necessary to regain fasting glycaemia.

Absorption is much longer after a meal based on starch, and takes, in general, more than 6 hours. This time also varies with the type of starch : maize starch is more rapidly digested than manioc starch. Raw potato starch does not appear to result in a very high absorption of carbohydrates, and it would be of interest to know the manner in which it is digested in the pig. Similarly, lactose is absorbed very slowly, and only produces a very slight increase in portal glycaemia.

In addition, technological treatments (swelling, dextrinization, solubilization of starch) bring about in increase in the rate of digestion and absorption of glucose into the portal vein. In this way, gelatinized starch is digested quicker than the raw maize starch, and the dextrins are digested and absorbed more rapidly with increased solubility.

The main results obtained at the moment only allow a qualitative description of carbohydrate absorption to be given, but we hope soon to be able to formulate a quantitative description.

\title{
ÉTUDE DU TRANSPORT DES ACIDES GRAS PAR LA VOIE LYMPHATIQUE CHEZ LE PORC
}

\author{
Lucie FRÉMONT \\ Station de Recherches de Nutrition, \\ Centre national de Recherches zootechniques, I. N.R.A. \\ 78 - Jouy-en-Josas
}

Les lipides alimentaires, après avoir été absorbés par la paroi intestinale, sont collectés par le système lymphatique qui les déverse dans le sang.

L'analyse des lipides de la lymphe intestinale permet donc de connaître le sort des lipides exogènes au cours de la digestion et de l'absorption.

Des graisses naturelles ( $98 \mathrm{p}$. Ioo de triglycérides) ont été administrées à des porcs munis de fistules lymphatiques. Moins de Io $\mathrm{mn}$ après avoir été ingérés, les lipides apparaissent dans la lymphe, leur concentration augmente pour atteindre un maximum 4 à $8 \mathrm{~h}$ après l'ingestion.

Pendant cette période, les proportions des acides gras sont du même ordre dans l'ingéré et dans la lymphe. Cependant, si l'ingéré renferme un taux élevé d'acide stéarique, la proportion de cet acide gras est plus faible dans la lymphe que dans l'ingéré. Il a été montré par ailleurs que l'utilisation digestive de cet acide gras est médiocre. 